\title{
"Eu mato": The Linguistic and Religious Rewriting of the Tupí under Portuguese Missionary Rule (1555-1630)
}

\section{Marlena Petra Cravens}

\begin{abstract}
This paper investigates the relationship between Portuguese missionary grammars, imperialindigenous relations, and Tupí resistance between 1555 and 1630. Focusing on José de Anchieta's popular grammar Arte de gramática de língua mais usada na costa do brasil (1555) and Luís Figueira's Arte da Língua Brasilica (1621), it argues that the shifting focuses of these texts represent the values of the Jesuit order and the interests of Portugal in the New World. Portuguese missionaries moved from an earlier emphasis on trade and Christian conversion with an exclusively oral culture toward a more aggressive and insidious campaign for cultural and linguistic erasure in the region. While previous scholarship has examined changes in Tupí phonemes, morphemes, and syntax between the grammars, this study instead investigates the historical changes pertinent between these texts, their constructed relationships between Portuguese and Tupí, and shifts in their lexical emphases.
\end{abstract}

Keywords: colonial translation; grammars; Jesuit missionaries; cultural erasure; Tupí-Guaraní

Résumé : Dans cet article, l'auteure analyse la relation entre les grammaires des missionnaires portugais, les relations empire-autochtones et la résistance des Tupis entre 1555 et 1630 . L'étude est axée sur la célèbre grammaire de José de Anchieta, Arte de gramática de língua mais usada na costa do brasil (1555) et celle de Luís Figueira, Arte da Língua Brasílica (1621). II ressort que les priorités changeantes de ces textes représentent les valeurs de l'ordre des Jésuites et les intérêts du Portugal au nouveau monde. Effectivement, les missionnaires portugais ont évolué : ils ont d'abord mis l'accent sur le commerce et la conversion chrétienne avec une culture orale exclusivement, puis ont adopté une campagne plus agressive et insidieuse d'anéantissement culturel et linguistique dans la région. Si ce sont les changements au niveau des phonèmes, des morphèmes et de la syntaxe de la langue tupi d'une grammaire à l'autre qui étaient sujet d'étude, ce travail s'attarde, lui, sur les changements historiques pertinents entre les ouvrages, la relation construite entre les Portugais et les Tupis et les changements au niveau des emphases lexicales.

Mots clés : traduction coloniale; grammaires; missionnaires jésuites; anéantissement culturel; TupiGuarani

Resumen: En este artículo se investiga la relación entre las gramáticas de los misioneros portugueses, las relaciones imperiales-indígenas y la resistencia de los tupíes entre 1555 y 1630 . Tomando como objeto de estudio la gramática popular de José de Anchieta, Arte de gramática de língua mais usada na costa do brasil (1555), y el Arte da Língua Brasílica (1621) de Luís Figueira, se argumenta que los focos cambiantes de estos textos representan los valores de la orden de los jesuitas y los intereses de Portugal en el Nuevo Mundo. Los misioneros portugueses pasaron del énfasis inicial en el comercio y la conversión al cristianismo con un enfoque exclusivamente oral hacia una campaña más agresiva e insidiosa dirigida a la erradicación lingüística y cultural en la región. Si bien en obras académicas anteriores se han abordado los cambios en los fonemas, morfemas y la sintaxis tupí entre las gramáticas, el presente estudio investiga los cambios históricos pertinentes entre estos textos, sus relaciones construidas entre los portugueses y los tupíes, y los giros en sus énfasis léxicos.

Palabras clave: traducción colonial; gramáticas; misioneros jesuitas; erradicación cultural; tupí-guaraní 
M. Cravens - "Eu mato": The Linguistic and Religious Rewriting of the Tupi

Resumo: Este trabalho investiga a relação entre as gramáticas dos missionários portugueses, as relações entre o império e o povo indígena e a resistência tupi entre 1555 e 1630. Tomando a conhecida gramática de José de Anchieta, Arte de gramática de língua mais usada na costa do brasil (1555) e a Arte da Língua Brasílica (1621), de Luís Figueira, argumentamos que os enfoques cambiantes desses textos representam os valores da Ordem Jesuíta e os interesses de Portugal no Novo Mundo. A ênfase inicial dos missionários portugueses no comércio e conversão cristã, com uma cultura totalmente oral tomou mais tarde a forma de uma campanha mais agressiva e insidiosa de apagamento cultural e linguístico da região. Estudos anteriores analisaram mudanças nos fonemas, morfemas e sintaxe do Tupi entre as gramáticas, ao passo que este estudo se propõe a investigar as mudanças históricas pertinentes entre esses textos, as relações construídas entre o português e o Tupi, bem como as mudanças de ênfase lexical.

Palavras-chave: tradução colonial; gramáticas; missionários jesuítas; apagamento cultural; Tupi-Guarani

\section{Introduction}

In 1555, José de Anchieta (1534-1597) completed the Arte de gramática de língua mais usada na costa do brasil (Zwartjes, Portuguese Missionary Grammars 165). Inspired and disturbed by difficulties in communication with Tupí-speaking peoples, he wrote the grammar in order to facilitate their conversion to Christianity and to ameliorate ongoing problems with trade relations. In spite of not being officially published until 1589, it was a vastly popular manuscript that was hand-copied and distributed among his clerical peers for use in communicating with the coastal Tupi populations (Zwartjes, Portuguese Missionary Grammars 165; Laborie 64).

This grammar forced European orthographic, phonemic, and semiotic standards upon the Tupí community, which contained a myriad of different dialects. These "standards" imposed elements like Western script, phonemic distinctions, and European linguistic meaning on an exclusively oral language that was fluid, highly contextual, and subjective (Santiago 13). In describing bilingual grammars, Roman Jakobson argues that grammars should "define what unifies and what differentiates the two languages in their selection and delimitation of grammatical concepts", balancing comparatively between the two languages (115; my emphasis). ${ }^{1}$ However, Early Modern missionary grammars also served another purpose: the conversion of indigenous populations through the translation of their language into the framework of Latin and, in this case, Portuguese (Hovdhaugen 14). With Portuguese as the target language, the grammar undermines

\footnotetext{
${ }^{1}$ While Roman Jakobson's argument ostensibly addresses modern grammars and their functions, the act of comparison between one language and another is not a new practice. In his Gramática de la lengua castellana dirigida a las escuelas (1796), Josep Pau Ballot emphasizes the importance of students observing "la analogía de ambas lenguas" ("the analogy of both languages") (n.p.). This argument for comparison and the issue of nonequivalence between languages dates to at least Antonio de Nebrija's Dictionarium latino-hispanicum (1492), in which the author writes that Latin and Spanish lack equivalents for many words and things, due to lexical changes over time: "Por el contrario muchas cosas hay en nuestro siglo: las cuales el antiguedad [...] no conoció" ("On the contrary, there are many things in our century that antiquity did not know") (fol. 3v) and "los vocablos juntamente nacen y mueren con las cosas" ("words are born and die together with the things [that they describe]") (fol.4r). In his Arte de la lengua castellana (1492), Nebrija emphasizes the importance of looking at Spanish words "en comparacion" ("in comparison") with Latin and Greek (n.p.).
} 
Tupí orality while simultaneously imposing a regime of Latinate script, meaning, and culture.

Luís Figueira (ca. 1574-1643) wrote his Tupí grammar in the 1620s and titled it Arte da Língua Brasílica. Rather than taking into account regional differences, he focused even further on standardizing an overarching, generalized Tupí language, similar to what has been observed in Spanish missionary work with Quechua (Clements 161). ${ }^{2}$ Anchieta's grammar influenced Figueira and he purposefully cited Anchieta in his own dedicatory preface. Nevertheless, he also wanted to create something more authoritative: in aiming to depart from Anchieta's grammar, Figueira's book includes an approbation by Manoel Cardoso that attacks Anchieta's grammar as "muy diminuta y confusa." ${ }^{3}$ This initial criticism reveals some of the insidious purposiveness and the power-related, interlingual qualities of the Portuguese conversion project. After establishing the inferiority of Anchieta's grammar and reducing a myriad of indigenous languages to what he describes as a single "Língua Brasílica" ("Brazilian Language") Figueira devotes an entire twenty pages to conjugating one verb: "matar" ("to kill") (12-33). The missionary emphasis on "matar" is both deliberate and pronounced, inflected by regional violence and Jesuit encounters with extractive transatlantic economies.

The shifting focus of these texts over time represent the values of the Jesuit order and the interests of Portugal in the New World. While some work has been done to examine changes in Tupí orthography, phonemes, and observed grammatical structures between the Arte de gramática and the Arte da Língua Brasilica, ${ }^{4}$ no work has been done to examine how these texts and their lexical emphases, correlating between Portuguese and Tupí, have changed over time. This paper will compare sections of these two grammars in order to articulate the problematic intersection of religion, colonialism, and language in the period between 1555 and 1630.

This comparative study will illuminate how linguistic and religious codes were closely intertwined with the domination of coastal indigenous groups. Additionally, it will explore Portuguese colonial translation techniques prior to 1700 and enumerate some of the problems inherent to the translation of an exclusively oral language into a written sign system (Jakobson 114). As Maria Tymoczko notes, the "neglect of orality in interpretation studies" destabilizes the very terms we use to explore literature and the workings of literature (53). Similarly, neglecting the orality of the "língua geral" of the coast in these grammars erases multiple important aspects of its speakers, its interpreters, and the power dynamics that complicate their interactions. ${ }^{5}$

\footnotetext{
${ }^{2}$ In his "Prologo ao leitor", Figueira refers to his target population as "Indios do Brasil" and to their language as the "Língua Brasilica", which oversimplifies the regional, social, and linguistic boundaries of Brazil's many indigenous populations.

3 Trans.: "very minute and confused."

${ }^{4}$ See: Zwartjes, Otto. "Missionary linguistics in Brazil." Portuguese Missionary Grammars in Asia, Africa and Brazil, 1550-1800. Philadelphia: John Benjamins Publishing Company, 2011. 134-204. Other works that approach this topic with the same lens include Yonne Leite's Línguas Indígenas: Memorias de uma pesquisa infinida (2012), and "O papel do aluno na alfabetização de grupos indígenas: a realidade psicológica das descrições lingüísticas" (1997); and Aryon Rodrigues's "Descripción del tupinambá en el período colonial: el Arte de José de Anchieta" (1997).

${ }^{5}$ Many thanks to my anonymous reviewers for their generous feedback and to my copy editor for the detailed commentary. Thanks also goes to María Constanza Guzmán, editor-in-chief of Tusaaji, and to Lorraine Leu for her encouragement, feedback, and overarching perspective. At the Newberry Library, Brown University, the Folger Shakespeare Library, and the Library of Congress, my thanks goes to Paul
} 


\section{Methodology}

This study interprets the intersection of religion, colonialism, and the translation of language between 1555 and 1630 in Jesuit Brazil. To do so, it draws from Simão Cardoso's detailed catalogue, Historiografia gramatical (1500-1920), to determine which extant texts to use-notably Anchieta's and Figueira's grammars (226-227). ${ }^{6}$ Supplementing this survey, Otto Zwartjes's analysis offers sound definitions for the role and function of these grammars, as well as the historiography surrounding Portuguese linguistic practices in Brazil (Portuguese Missionary Grammars in Asia, Africa and Brazil, 1550-1800). Zwartjes argues that scholars that study the "history of linguistics in the early modern period have been concerned ... with writings on the vernaculars of Europe", rather than with the "non-Indo-European languages from the same period" (2). His text rectifies these deficiencies, concentrating on the missionary texts produced in Brazil, Japan, India, and Africa.

Zwartjes uses Even Hovdhaugen's foundational definition of a missionary grammar as a starting point for his analysis. According to Hovdhaugen, a missionary grammar is "a description of a particular language created as part of missionary work by non-native missionaries ... It is a pedagogical, synchronic grammar covering phonology, morphology and syntax based on data mainly from an oral corpus" (Hovdhaugen 15; Zwartjes, Portuguese Missionary Grammars 1). These grammars, while used in missionary work, contributed to the broader study of the "typology of languages" (2). Structurally, the Portuguese missionaries used a Greco-Latin framework for their grammars, organizing around themes of phonology, orthography, noun declension, and verb conjugation, in order to ease the process of new missionaries learning the tongue of their converts (Zwartjes, Portuguese Missionary Grammars 20; "The Description" 20). ${ }^{7}$ This imposition of Latin structures is not unique to Brazil, and can also be seen in Spanish interactions with Nahuatl, Quechua, Aymara, Tagalog and many others (Santo Tomás 1560; Molina 1571; Bertonio 1603; González Holguín 1608; Blancas 1610). As these missionaries were conversant with Latin pedagogical strategies, the mapping of the Latin structure onto foreign languages made the process of learning easier for priests. Zwartjes also highlights the important inclusion of a lexicon while learning from the grammars;

\footnotetext{
Gehl, Lia Markey, Analú López, Andrew Laird, Owen Williams, Stephanie Stillo, and all of the archivists that made this article possible. My gratitude to my advisors-César Salgado and Michael Harney-as well as Cory Reed, Ann Twinam, and Adrian De Leon for their support and feedback. Thanks also goes to Maclain Scott, Lisa Bernabei, and Jellybean Hamnet Cravens who all supported my work on this article in their own ways-and to George Cravens and Catherine Cravens, for showing up uninvited and hiding in a hallway. Lastly, I thank my panelists at the 2016 Institute for World Literature, the 2017 Newberry Graduate Conference, and the 2018 Latin American Studies Association for their feedback and thoughtful questions. ${ }^{6}$ This study uses Anchieta's 1595 imprint and the 1687 version of Figueira's text. The disparity between Figueira's original date of publication (1621) and the version used for this article is due to the 1687 version having clearer pagination and a definitive printing date. Various grammars identified as Figueira's 1621 version lack a clearly printed date and have only been tentatively identified.

${ }^{7}$ While not directly within the purview of this paper as a lexical examination, Zwartjes points to the Jesuit use of De Institutione grammatica (1572) by Manuel Álvares (1526-1582) in his article "The Description of the Indigenous Languages of Portuguese America by the Jesuits during the Colonial Period." Other Portuguese grammars that may have influenced the structures of New World grammars include Fernando Oliveira's Grammatica da lingoagem portuguesa (1536) and João de Barros's (1540) Grammatica da lingua Portuguesa.
} 
missionaries could assimilate new vocabulary, gradually introduced page by page, while learning the grammatical structures of the languages (Portuguese Missionary Grammars 20). An expanded vocabulary was critical for administering the catechism and taking confession successfully, and to that end many grammar authors also compiled vocabularios, or dictionaries, as complementary texts (Molina 1555; Santo Tomás 1560; Alvarado 1593; Holguín 1608). In the case of Tupí, no such vocabulario exists.

While Otto Zwartjes, Aryon Rodrigues, and others elucidate on the organization and structures of the grammars, they do not account for the problematic power negotiation inherent to translating Tupí orality into Portuguese textuality, and the strategic value of the vocabulary translated. They study the syntax of the grammars in depth, rather than the lexicon used by Anchieta and Figueira to create their example sentences. Finally, while they analyze the structures of the grammars-phonemic organization, verbs, prepositions, and nouns - they do not use the front matter of each grammar, which is critical to understanding the publication history that defined authorial success and what these Jesuits describe as their aspirations. This study extends the work of the aforementioned authors in order to begin to address these facets, holistically assessing lexical data in dialogue with historical trends and the publication histories - through the prolegomena-of these texts.

Because of the dearth of information related to lexical concerns, lightly touched on by works like Aryon Dall'Igna Rodrigues and Ana Suelly Arruda Cámara Cabral's "A Contribution to the Linguistic History of the Língua Geral Amazónica" and Yonne Leite's Línguas Indígenas: Memorias de uma pesquisa infinida, ${ }^{8}$ this paper will rely upon the concepts proposed by translation scholars such as Roman Jakobson, Itamar Even-Zohar, Susan Bassnett, Michael Cronin, Tejaswini Niranjana, and André Lefevere to elaborate on the necessary and systematic exploration of the "polysystem" or historical context that informs the creation of these grammars. This "polysystem", as will be elaborated more fully, highlights the critical importance of the "interpenetrating" context of the grammarsculturally, literarily, and historically - as they defined history and as history defined them ("Word and Image" 16). Susan Bassnett and André Lefevere emphasize the ways that power dynamics, and the divide between colonizer and colonized, problematize the particular polysystem of a text. Their work will delimit the manner used to approach the historical context. ${ }^{9}$ Furthermore, Maria Tymoczko's tripartite conceptualization of orality and her argument for the role of the interpreter ("Translation in Oral Tradition") provides the framework for a comparative approach to the analysis of these texts.

\section{Historical Contextualization}

An analysis of these grammars requires an examination of the historical context in which they were produced, tracing the history of Tupí-Portuguese encounters from early written accounts. I rely on modern translation theories and philological research for this

\footnotetext{
${ }^{8}$ Rodrigues and Cabral's work examines the relationships between known Tupi dialects over 300 years, rather than looking at relationships of power and erasure between Portuguese, Latin, and Tupí. They argue that the generalized "Língua Geral Amazônica" is a type of the Tupinambá language and that the two languages are indeed closely related.

${ }^{9}$ While these translation theorists confirm and justify the need for a historical approach to the grammars, their theories do not inform the specific methods used here to analyze them.
} 
process, including Even-Zohar's theory of the polysystem ("The Position of Translated Literature"), Lefevere and Bassnett's work on publishing and audience demands ("Introduction"), and Niranjana's work on strategic translation in a colonial context (Siting Trans/ation), interrogating the inherent problem of power and authorship. These theories are supplemented by and modelled from the philological and historical work of Rafael (Contracting Colonialism), Rodrigues (“Descripción”), Calvo Pérez (2005), Hanks (Converting Words), Leite (Línguas indígenas), Muru ("Early Descriptors"), and Zwartjes, who have examined missionary grammars in their respective fields.

According to Even-Zohar, a "polysystem" includes all the systems that inform the production and success of a translation, as it is part of a "cultural, literary and historical" milieu (Even-Zohar 195-197; Munday 164). The grammars, in this type of Geertzian "thick description", should necessarily be studied alongside their contexts and not in isolation; this sensitivity allows for scholarly criticism to concentrate on the overarching goals of the translation and on the grammars as historical record, rather than on changes in grammatical characteristics between the two texts (Geertz 12).

Translation theorists Bassnett and Lefevere agree with this approach, but emphasize that while addressing broad historical contexts, translation scholars must also focus on the mechanics behind translation proper and a translation's success (Lefevere and Bassnett 11, 12; Munday 192). Therefore, "context" in their framework dictates everything from "how a text is selected for translation" to "what role an editor, publisher or patron plays" (Bassnett 123; Rafael 4). Extended further, this process includes translator strategies that are determined by external pressures and personal preference, as well as a translator's awareness of "how a text might be received in the target system" (Bassnett 123). Translation practices and translations themselves are not just passive entities; they are a "major shaping force for change" in a historical period (Bassnett 126). Rather than simply exemplifying a period in history, a translation also guides contemporary ideological forms through its incorporation or rejection of ideas, especially as the text rises in popularity. Therefore, translations conceal a certain insidious quality: "[they are] the primary method of imposing meaning while concealing the power relations that lie behind the production of that meaning" (Bassnett 136).

Other scholars, like Niranjana, extend this line of reasoning, arguing that "translation reinforces hegemonic versions of the colonized ... [producing] representations or objects without history" (3). The creation of these grammars for an oral language divorces the language from its context and its social mores, dehistoricizing Tupí linguistic culture. Even the term "Tupí" is a synecdochal borrowing of the prefix "Tupi-" by Europeans to characterize and reduce the Tupi-Guaraní tribes that used the prefix in their self-appellations, like Tupina, Tupinambá, and Tupiniquin (Kittiya Lee 78). With these concepts in mind, analyzing these grammars requires attention to the historical context in which they were produced, particularly in terms of the experiences of the Portuguese and Tupí leading up to Anchieta's arrival, followed by Figueira's own experiences between 1550 and 1630; it also requires an awareness of Brazilian publishing history in the period.

The Portuguese history of writing what Niranjana would call "hegemonic [European] versions" (3) of the Tupí peoples begins in 1500 with their earliest recorded interactions. ${ }^{10}$ When Pero Vaz de Caminha made landfall on tierra firme, his letter to the

\footnotetext{
10 Tejaswini Niranjana's take on translation as a producer of "hegemonic versions" or representations of colonized peoples-creating "objects without history" and reducing cultures and faces to quaint items on
} 
King of Portugal described the tribes he encountered as "índios brasileiros [que] estariam naturalmente inclinados á conversão religiosa"11 and that they "imitavam os gestos dos cristãos durante o santo sacrifício da missa" (Santiago 15; de Caminha 41-54). ${ }^{12}$ This imitation of Christian gestures invited conversion attempts and later justified the priestly interest in imposing reductions after 1610, which forced small communities into larger communes that made catechizing the population easier (de Abreu 94-95). Silviano Santiago emphasizes that the imposition of Portuguese culture and arbitrary violence did a lot to cause the "vitória do branco no Novo Mundo", ${ }^{13}$ but that much of the "brutal imposition" came from the language used to describe indigenous groups, from the "recorrência das palavras "escravo" e "animal" nos escritos dos portugueses e espanhóis" (Santiago 13). ${ }^{14}$ What these words suggest is the imposition of the "ponto de vista dominador", ${ }^{15}$ a cultural text, upon the Tupí tribes that existed without a written language with which to defend themselves (Santiago 13). Like colonizers and traders, the Jesuits referred to Tupí-Guaraní speakers as "Tupis" or "Tupi Indians" in their letters, reducing them to a fragment of their identity. ${ }^{16}$

The Jesuits dominated ecclesiastical matters throughout the 16th and 17th centuries in Brazil and were "pre-eminent in educational, evangelical and cultural activities" (Zwartjes, Portuguese Missionary Grammars 143-144; Macdonald 55-56). As the Portuguese Crown had little interest in the Brazilian colonies at that time-in contrast to India and Japan - the Jesuits were left to their own devices, creating methods of communication and coexistence that were relatively unrestricted by the crown and which concentrated on Christian conversion (Bethell 286; Zwartjes, Portuguese Missionary Grammars 144; de Abreu 26). In the first few decades after landfall, arriving ships and their settlers traded for brazilwood, sugar, and later tobacco (Macdonald 54, 103). With increased profit came increased competition over access to the coast, fuelled by French, Dutch, and Portuguese land claims (Wehlig 126-142).

This international competition and greed played a role in the rapidly escalating violence over territory. The French, unlike the Portuguese settlers, based trading on apparent goodwill and friendship with coastal tribes, profiting off the fact that French privateers and settlers did not owe the royal fifth to their king. The fierce enmity between the Portuguese and French was a mirror of the enmity between the Tupiniquins and the Tupinambás, two groups that spoke the lingua geral of the coast. The Tupinambá allied with the French — called "Mairr"-and the Tupiniquins sided with the Portuguese, who they called the "Peró" (de Abreu 31; de Almeida 71-141). The French strategically pitted the Tupinambá against the Portuguese by contrasting their intimations of friendship with Portuguese violence, though they were just as extractive and brutal. Additionally, the Jesuits themselves were shocked by the violence of their own Portuguese settlers-

display for a European readership—cannot be overemphasized.

11 Trans.: "Brazilian Indians that would be naturally inclined to religious conversion."

12 Trans.: "[they were] imitating the gestures of Christians during the holy sacrifice of the mass" (my emphasis).

13 Trans.: "victory of whiteness in the New World."

${ }^{14}$ Trans.: "reoccurrence of the words 'slave' and 'animal' in the writings of the Portuguese and Spanish."

15 Trans.: "dominant point of view."

${ }^{16}$ See: José de Anchieta, "Informação do Brasil e de suas Capitanias - 1584", in Cartas, Informações, Fragmentos Históricos e sermões do Padre Joseph de Anchieta. Rio de Janeiro: Civilização Brasileira, 1933. 
grasping for more slaves and further profit-and they felt it was their moral duty to reeducate them all while simultaneously converting the indigenous groups along the coast (Macdonald 101). Missionaries like José de Anchieta and Manoel da Nóbrega, however, felt that many Portuguese were "bad Christians" beyond saving due to the fact that their colonists had knowledge of Christian goodness and still strayed from the path; the conversion of the Tupí was more practical, especially if they were able to convert Tupí children first (Diffie 109; Macdonald 101; de Abreu 48-49).

By merging the education of Tupí and Portuguese children within villages, Jesuits believed they could then influence, or re-educate, their parents (Macdonald 101; Kittiya Lee 127, 128). On January 25, 1554, Anchieta and Nóbrega established a school in São Paulo de Piratininga near the Portuguese township of Santo André, whose inhabitants resented the reduction of their slave supply (Rodrigues 373; Zwartjes, Portuguese Missionary Grammars 148). Living in Piratininga, Anchieta likely acquired the dialect of the Tupiniquin in the area rather than the dialect of the Tupinambá (Rodrigues 373).

José de Anchieta (1534-1597) was a key figure in many conflicts between the Portuguese and the Tupi and he trusted heavily in the positive reputation of the Jesuits among the southern Tupí, especially during the uprisings at São Paulo and Santo André (1562) and later at Iperoig (1563-1565) (Macdonald 109-110; de Abreu 58; Diffie 111, 129-131). Relying on his linguistic abilities and knowledge of the Tupi and Portuguese, he quelled some of the violence between them by facilitating communication as an interpreter. ${ }^{17}$ After developing his abilities with the língua geral (general language) throughout his time in Piratininga, he further honed it by translating during conflicts. He created the earliest manuscript of his grammar between 1555 and 1560 , and the text underwent revisions with his experiences as an interpreter (Zwartjes, "The Description" 23; Rodrigues 373,392 ). The Jesuits in the region relied on his grammar to communicate and copied it by hand until it reached Antonio de Mariz's printing press in Coimbra, Portugal (1595).

In contrast to southern Brazil, the Jesuits were not active in Maranhão until the 1600s. When they arrived with the intention of converting and reducing the rate of enslavement, they were shocked by the resistance and extreme violence they met. In the northeast, indigenous groups had suffered immensely due to being enslaved, with many populations having been wiped out entirely or having fled toward the interior (Macdonald 261). The settlers in the region had long been living unrestricted by officials and they opposed both the Crown and the Jesuits on the matter of slavery, violently resisting any decrees that limited their rights to enslave others. Additionally, the vicious conflict with the French (1612-1615) and Dutch (1641-1644), who harried the region and variously held Maranhão as a colony, left many settlers very hostile and unwilling to change their ways (Magalhães 376). The intense competition for access to these sugar-producing regions fomented further conflict in the states of Bahia and Pernambuco (1630-1650), and limited access to Maranhão (Wehling 126-142).

In 1607, Luís Figueira (c.1574-1643) travelled with Father Francisco Pinto (15521607 ) to establish a mission in Maranhão and was turned back when a tribe "in the

\footnotetext{
17 This summary focuses on his work as an interpreter, but it is important to note that Anchieta was not a pacifist. He believed that violence and force were necessary in instances where indigenous populations could not "be civilized" by abstaining from ritual cannibalism, alcohol, and other "vices" (Diffie 121, 109; de Abreu 48).
} 
Ibiapaba mountains" killed Pinto (Kittiya Lee 137). Figueira chose to make the slow journey back to Pernambuco and report on his experiences. In 1615, he tried to establish another mission in Maranhão, this time with Jesuits Lopo do Couto and Bento Amodei (de Abreu 106). He also had the support of Alexandre de Moura, who was determined to capture the "French fort at São Luís" (Kittiya Lee 137). This fort would later fall into Dutch hands (de Abreu 106-107). Figueira and his compatriots finally founded a mission in 1622 (Zwartjes, Portuguese Missionary Grammars 164). As a Jesuit, he held the same beliefs in conversion as Anchieta, but his experiences in the northeast of Brazil were clouded by the ever-increasing violence between all factions in the region.

Despite Figueira's efforts, the constant conflict between tribes and greedy settlers made the region perilous and too volatile for conversion. He returned to Portugal in 1636 (Zwartjes, Portuguese Missionary Grammars 164). His grammar was shipped to Lisbon some time before his return and Manoel da Silva printed it in 1621, while Figueira was still in Maranhão. The text was used widely due to its accessibility and its ability to "abrir as vias de comunicação entre os missionários e os índios do Maranhão" (Magalhães 376, $377) .{ }^{18}$ With his successful publication and renewed vigour, Figueira organized a return voyage to Brazil, but the ships sank in 1643 near Sol Bay within sight of the coast (de Abreu 106-107). In summary, Anchieta and Figueira had very different experiences with conflict in their role as interpreters; however, they both operated under Jesuit practices of language pedagogy and acquisition.

Jesuit linguistic studies in the period divided the languages of Brazil into two categories. The first category comprised the "Tupi"-identified tribes that belonged to the Tupí-Guaraní language branch. This group included the dialect in Piratininga, the variety of Tupí that Anchieta knew best and described in his grammar (Macdonald 43). Roughly sixteen tribes spoke Tupí, all along the coast and into the interior of Brazil. This language was called the língua geral (general language) by the Portuguese, as it was the most widespread and therefore the most useful (Zwartjes, "The Description" 26; Clements 160). Recalling Silviano Santiago's argument regarding naming, language, and ideology, ${ }^{19}$ the "geral" label is not only generalizing but privileging, standardizing a complicated and exclusively oral language with many dialects into a broadly intelligible tool for empire. The second language group contained the linguas travadas, or "tongue-tied" languages, and this group was a mixture of languages that the Jesuits were simply unwilling or unable to classify beyond that it was not Tupí (Diffie 20). The eastern Brazilian language Kipeá Kiriri-from Luiz Vincencio Mamiani's Arte de gramatica de lingua brazilica da Naçam Kiriri (1699)-is the only non-Tupí language from the tongue-tied language group that Jesuits documented through "extant grammars, catechisms and wordlists" (Zwartjes, Portuguese Missionary Grammars 176-177; Rodrigues 371).

The Jesuits viewed Christian conversion as instrumental to indigenous salvation, one of their primary duties in the settlement of Brazil. With the target of communicating Christianity, some missionaries participated in rituals and dances in order to better understand Tupí culture and religion (Macdonald 184). The mimicry of Tupí traditions, as well as the intense scrutiny of Tupí religious practices, emphasizes how interested the

\footnotetext{
${ }^{18}$ Trans.: "open the pathways of communication between the missionaries and the Indians of Maranhão."

${ }^{19}$ Through choice in language, one can impose a "culture and arbitrary violence", like the emphatic use of the words "slave" and "animal" in Portuguese and Spanish writings regarding the peoples of the New World (Santiago 13).
} 
Jesuits were in the process of conversion through the points of contact between Catholicism and the Tupí religion. ${ }^{20}$ Father João de Azpilcueta Navarro (1522-1577) went so far, after mastering the Tupí language, as to "imitate the pajés during his sermons, stamping his feet, clapping his hands and adopting all of their other gestures", translating his Christian message onto their lifeways (Macdonald 184). ${ }^{21} \mathrm{~A}$ pajé, also known as a caraíba, represented "tudo o que os índios criam e ... sustentavam a cultura" of their community (de Paiva 80; de Abreu 12). ${ }^{22}$ The tidy parallels to Christian ideology suggested the possibility for conversion and a certain "willingness" to be directed toward the proper religious path.

To conclude, this understanding of the complex historical systems (ranging from economic and exploitative to religious) in which these translations of a lingua geral version of Tupí functioned, allow for an analysis of the power relations between Tupí orality and Christian textuality —and between Tupí and Jesuit—at work within the grammars. In order to understand the full extent of the role of the grammars in this period, this analysis will first examine the front matter of the grammars before moving onto an analysis of the semantic values at stake in the texts.

\section{Analysis}

The interlingual translation of Tupí into Portuguese was a complex act of interpretation because missionary listeners had to move what they heard into a system of written symbols that existed outside of the highly subjective spoken and social context of the Tupí community. This interpretive quality made forming a grammar a deconstructive act wherein missionaries had to assess how the language and its concepts worked relationally, parsing the built-in characteristics and assumptions of Tupí expressions; instead of superficially interpreting from one language into another, missionaries also needed to interrogate their own translating processes in order to define the grammar rules in their target language. In interpreting Tupí, then, they also had to examine their own Portuguese, linking to Jakobson's argument that grammars are inherently comparative, "defin[ing] what unifies and what differentiates ... two languages in their selection and delimitation of grammatical concepts" (115). Whenever there is a fault or inability to communicate meaning, "terminology may be qualified and amplified by loan-words or Ioan-translations, neologisms, or semantic shifts", as has been observed in Quechua and Tagalog translations (115). Vicente Rafael notes that Jesuits working in the Philippines preserved religious terms like "Dios, Virgen, Espíritu Santo, Cruz" and others (Contracting Colonialism 29). In the instance of Domingo de Santo Tomás's Quechua dictionary (1560), he altered religious words to fit the appropriate Quechua endings, like "Sancta

\footnotetext{
20 The obsession with "true" conversion is not unique to the Portuguese and was an important part of the Jesuit agenda across national lines. In his book on the inherent relationship between Spanish translation, conversion, and conquest in the Philippines, Vicente Rafael highlights how priests lived in a near-constant state of skepticism regarding whether their flocks had legitimately converted or were simply "parroting" a priest (Contracting Colonialism: Translation and Christian Conversion in Tagalog Society Under Early Spanish Rule, 1988).

21 Jesuit research concluded that the Tupí believed in the "existence of a promised land 'beyond the mountains' where the souls of their dead journeyed", not too far removed from some principle beliefs in Christianity (Macdonald 46).

22 Trans.: "everything that the Indians believed and [that] sustained (or underpinned) their culture."
} 
Mariacta", "Sancto Domingocta", and "Diospa" as "Santa Maria", "Santo Domingo", and "Dios", respectively (76). These mechanisms likewise inform the lexical interpenetration between Portuguese and Tupí, while also bringing to the fore the complexity required to navigate shifting an oral language and culture into a written from.

Maria Tymoczko emphasizes the problem of orality in translation studies, especially as it is neglected and under-theorized. According to Tymoczko, the act of interpreting imposes a "process" upon texts, manipulating them as they move from an oral system to a textual system (46). She proposes that there are three types of interaction with orality: the movement from fixed text to oral text, the movement from oral text to oral text, and the movement from oral text to written text (Bohannan 27-36; Tymoczko 50). She concludes in the case of oral-to-written translation that the very act of preserving and translating oral texts already highlights a valuation of the language being translated (Tymoczko 51). However, translations of oral languages and their norms must be adapted or "naturalized" toward the "receptor culture", and can "adopt the motifs, themes, formulas and other structures" that will make them understandable (Tymoczko 52, 53). In the instance of Jesuit grammars, this "process" would then include linguistic adaptation via the imposition of Jesuit-palatable ideologies and poetics (Tymoczko 46; Bassnett 123, 136). Tupi will be "pulled into the framework" of Portuguese cultural norms and missionary expectations (Tymoczko 54).

To further complicate matters, Michael Cronin emphasizes the role of the interpreter in the process of oral-to-written translation, arguing that in many ways the interpreter occupies the place of a cultural traitor that must "cross boundaries of gender, class, nationality, and ethnicity" (53). The Portuguese relied on a system that Cronin calls autonomous, meaning that the Portuguese preferred to train their own subjects in the "languages of the colonized" (Cronin 55). As Portuguese citizens were thought to be more trustworthy than an indigenous translator, these interpreters then used those languages to navigate violence and clear the way for colonial practices. ${ }^{23}$ He cites Pero Vaz de Caminha's descriptive letter as one such example: in it, de Caminha writes that his captain, Pedro Álvares Cabral (1467-1520), left two condemned sailors on the shore, feeling that they would "give better information than those men" that were seized from the coast (Cronin 55-56; de Caminha 49; Diffie 17). In general, indigenous interpreters or "informants" were always suspected of deliberately sabotaging translation efforts or betraying the language of conversion by never truly understanding it (Hovdhaugen 14; Muru 5; Rundle and Rafael 26). Overall, an interpreter had to navigate "hierarchical relationships of power" in order to stay alive, retain legitimacy, and be successful in conveying meaning (Cronin 58; Laborie 58).

To examine the placement of Anchieta and Figueira within their interpretive and functional contexts, I examined the front matter of their grammars before moving onto the analysis of specific lexical decisions. In Anchieta's brief prologue, he very clearly begins by identifying himself and his role as a Jesuit. In addition to having royal approval from "Sua Alteza"24 ("your highness") in 1594, the "licença" ("license") by Augustinho Ribeiro states that it "servirão muyto pera melhor inftruçao do Cathecumenos, \& augmento da

\footnotetext{
${ }^{23}$ The other option is called "heteronomous" and "involves recruiting local interpreters and teaching them the imperial language"-recruiting in this case often implied kidnapping or horrific forms of bribery (Cronin 55).

${ }^{24}$ Likely King Phillip II (1527 -1598), who at this time ruled both Spain and Portugal.
} 
noua Chriftãdade daquella partes, \& pera com mais fecilidade \& suauidade fe plantar \& dilatar nellas nossa Jancta Fee" (n.p.). ${ }^{25}$ While Anchieta acknowledges regional variation, his title argues for a grammar "Da lingua Mais Usada na Costa do Brasil", ${ }^{26}$ which is strategic and more far-reaching in its consequences than a less-known language or dialect. ${ }^{27} \mathrm{His}$ opening section, in addition to his dedicatory preface and the approvals, is very methodical and structured, relying on headings and comparisons between Portuguese and Latin as hegemonic languages (5r, 6r, 10v-11r). He begins, as was traditional in European grammar-writing, with a description of Tupi phonemes, the sounds that make up Tupí words; in describing them, he establishes his own orthographic norms.

Figueira's text has not been as effectively preserved as Anchieta's; while the earliest version is said to be published in 1620, the version preserved in the Biblioteca Nacional de Portugal was published in 1628 (Magalhães 381). Zwartjes points out that Figueira's grammar relies on Anchieta's grammar and structure, but argues that the text never "mention[s] his name" (Portuguese Missionary Grammars 164). However, inside the text in the dedicatory preface, the prolegomena clearly destabilize Anchieta as a figure of authority on matters of the Tupí language and problematize his overall goals: "não obftante a arte do P. JoJeph Anchieta que por Ser o primeiro parto ficou muy diminuta, \& confuJa." 28 This criticism of his predecessor is further bolstered by support from Manoel Cardoso and others, who write that not only is Figueira the inheritor of a great traditionof the "herança de Seus Maiores os Anietas, os Nobregas, \& Almeidas"29_but that religious and linguistic authorities also approve of his work: "\& aprovâraõ ReligioJos doutos, \& verfados na lingua do Brafil." 30 Anchieta lacks this distinction, and appears in Figueira's text as well-intentioned but ill-informed, perhaps even misconstruing or misunderstanding certain words as he did not have the same official linguistic backing or background that Figueira had. As a rhetorical strategy, this paints Figueira's text as the definitive and authoritative version for those who wish to learn to speak Tupí. While it is the case that Figueira's text attempts to supplant Anchieta's, Figueira's prologue interestingly makes no explicit mention of the goal of converting the Tupí or teaching them the catechisms; he only states that his intended audience is those who wish to "saber esta lingua, pera ajudar a estes pobres Brafijs" (n.p.). ${ }^{31}$

This issue of cultural translation, even in the prefaces, is immediately apparent, as is a sensitivity for their readership. Claudia de Lima Costa notes that "the notion of cultural translation (drawing on debates on ethnographic theory and practice) is premised upon the view that any process of description, interpretation, and dissemination of ideas and worldviews is always already caught up in relations of power and asymmetries between

\footnotetext{
${ }^{25}$ Trans.: "will serve very much to improve instruction of the catechism and to increase new Christianity in those parts, and in order to plant, with more ease and gentleness, and increase in them our Blessed Faith."

${ }^{26}$ Trans.: "Of the language most used on the coast of Brazil."

27 The title of Anchieta's grammar generalizes Tupí, but acknowledges the regional "na costa" ("of the coast"), distinguishing it from the amazônica form of Tupi further inland. Similarly, he writes on the second page about the differences between dialects within the coastal variant, touching on the differences between the "Tamôyos do Rio de Janeiro" and the "Tupis de sam Vicente" (1v).

28 Trans.: "however the art of Father Joseph Anchieta, for being the first one [first birth], he made very minute and confused."

${ }^{29}$ Trans.: "inheritance of his betters the Anchietas, the Nóbregas, and Almeidas."

30 Trans.: "and approved by religious men learned and versed in the language of Brazil."

31 Trans.: "know this language, to help these poor Brazilians."
} 
languages, regions, and peoples" (de Lima Costa 63). ${ }^{32}$ However, not only are Anchieta and Figueira caught up in relations of power; I argue they were also caught up in relations of space. Both Anchieta and Figueira were limited in terms of how much lexical information they could include in their grammars. This spatial limitation grew out of two broad requirements: the limitations of grammar books themselves as a tool and the very process of creating a book.

The first type of limitation revolves around the structural and practical demands of the grammar as a text designed for efficiency and utility. As mentioned previously, Hovdhaugen describes a missionary grammar as "a description of a particular language created as part of missionary work by non-native missionaries ... covering phonology, morphology and syntax based on data mainly from an oral corpus" (Hovdhaugen 15). The intended audiences of the grammar were those missionaries who wished to communicate and convert a population that does not speak their language; to that end, the grammar's target function is to describe the very structure of the indigenous language itself on a practical level, offering a missionary the - often rudimentary - tools to open initial lines of communication. Figueira himself writes in his dedication "AOS RELIGIOSOS da Companhia de Jesus" 33 that "o methodo da Arte he facil, bem ordenado, \& breve" (n.p., my emphasis). ${ }^{34}$ As the books were intended to be small in size and portable, the Tupí lexicon that Anchieta and Figueira included is what they perceived to be the most strategic and the most useful. The words chosen for translation were those that were important for day-to-day life among different Tupí-speaking populations and critical for conversation in Tupí. They had to select and privilege the words that they thought would help the most missionaries to be successful in their duties (Zwartjes, "The Missionaries' Contribution" 1). These choices were a matter of space on the page but also an ethnographic matter, reflecting their interactions with the Tupí at what Anchieta and Figueira saw as their most fundamental level. The Tupi words that they selected to include reflect their own knowledge bases and the institutions imposed upon both themselves and upon the Tupi (de Lima Costa 63).

The second limitation, the process of bookmaking, compounded the functional limitations of the grammars. Brazil did not receive a printing press until 1808, when the entire Portuguese Court under João VI (1767-1826) moved to Brazil (Gauz 28, 39). ${ }^{35}$ All texts prior to 1808 had to survive being shipped from Brazil to a Portuguese printing press. Anchieta's grammar circulated for over thirty years as a manuscript in Brazil before it reached a printing press in 1595 (Rodrigues 373; Laborie 64). The early, informal copies that circulated among Jesuits were handwritten and cramped, limited by access to paper and ink. In isolated areas, restricted access to resources was further exacerbated by bloodshed between the French, Portuguese, and Dutch in conflicts with each other and against the Tupí. After reaching a printing press, grammars could then be expanded beyond handwritten notes for personal reference, but the goal remained: a small, accessible book that reduced a language to its simplest parts, uncomplicated by the elaborate copia, ${ }^{36}$ a term used to describe the expansive lexicons that were the hallmark

\footnotetext{
32 de Lima Costa draws her insights from Tejaswini Niranjana's Siting Translation (1992).

${ }^{33}$ Trans.: "TO THE DEVOUT of the Society of Jesus."

${ }^{34}$ Trans.: "the method of the Art is easy, well organized, and brief."

${ }^{35}$ Napoleon Bonaparte invaded Portugal in 1807, necessitating João Vl's departure (Gauz 39).

${ }^{36}$ Copia ("abundance") is quite frequently tied to pedagogical exercises in eloquence through the activity
} 
of indigenous-language dictionaries. ${ }^{37}$ William F. Hanks emphasizes the difference between grammars, also known as artes, and dictionaries: grammars are pedagogical tools that are "partly shaped by the lexical and semantic knowledge embodied in the dictionary. The two are mutually necessary" but serve different functions (205). In the case of Anchieta's grammar, it is likely that he reworked his text multiple times, even after leaving the Tupí in 1565 (Rodrigues 373).

Accordingly, European historical and linguistic traditions dictated the contents of Anchieta's work. He relied upon his education in Latin to design a grammar in the European style, paralleling Tupí pronouns with "mihi" ("me"), "tibi" ("you"), "nobis" ("us"), and "vobis" ("you" plural) from Latin (10v-11v). He also draws comparisons between both Portuguese and Latin, describing certain Tupí characteristics as "como no portugues" or "pronuncia mais portugues ou castelhano como quer" (5r, 6r; Rodrigues 375). ${ }^{38}$ Additionally, he is complimentary with his descriptors, arguing that the agglutinating process of Tupí has "Diversas maneiras claro, \& elegante pellos mesmos infinitivos" $(28 \mathrm{r}){ }^{39}$

Figueira, having based his grammar on Anchieta's, proceeds similarly, using Latin as his comparative language of authority and using the same comparative lens and "educational" style as Latin teachers. The hegemony of Latin in European education speaks to missionaries' training with Latin in the Church but also to their expectation that languages must fall into tiers of superiority and inferiority. While Figueira mimics Anchieta's complimentary approach-"ua lingua suave si, \& elegante, mas estranha, \& copiosa" 40 - he also identifies the "barbarity" of Tupí by comparing it to Greek: "Parecera barbaria, concordar Terceira pessoa no singular, com a primeira do plurar. Mas naõ he de eJstranhar, pois tambem na lingua Grega elegantiffima temos exemplo Jemelhante" (99). ${ }^{41}$ The comparison to Greek, a language considered inferior to Latin at least since Horace $(65-8 \mathrm{BC})$ and the project of translatio studii, ${ }^{42}$ crystallizes his argument that Tupí does not meet the standards and elevation of European Latin.

Lexically, Anchieta's text introduces a breadth of terms that allow one not only to coexist with the Tupí, but to administer the catechism and confession. He offers the vocabulary for bodies, both personal and familial. For example, he includes "meum

of amplificatio, rhetorical expansions on a given text using the different figures of speech (Moss 175-77).

${ }^{37}$ Alonso de Molina agrees. In the composition of his Arte (1571) for Nahuatl he argues that "para que este arte de la lengua Mexicana sea mas breve ... porquanto no pretendemos aqui escribir vocabulario sino arte" ("so that this grammar of the Mexican language will be shorter...we will not here try to write a vocabulary but rather an art") (5v-6).

${ }^{38}$ Trans.: "like the Portuguese" and "one pronounces it more like Portuguese or Spanish, as one likes it", respectively.

39 Trans.: "diverse ways, of course, and elegance for the same infinitives."

40 Trans.: "a gentle language yes, and elegant, but strange, and vast."

${ }^{41}$ Trans.: "It would appear a barbarity, making the third person in the singular like the first person of the plural. But we must not be surprised, because in the extremely elegant Greek language we have a similar example."

42 Translatio studii is the belief that transfers of knowledge happen linearly through history, with a rising empire taking the reins of knowledge production as its predecessor collapses, like Rome taking over from Greece. Horace writes in that vein in a letter to the Piso brothers: "For yourselves, my friends, you must give your days and nights to the study of Greek models" but the best Roman poets "enjoyed some of their greatest successes when they have had the courage to turn aside from the paths laid down by the Greeks, and sing of deeds at home" (106). 
corpus" ("my body") or "Xéreté", but also adds those of family members in order to establish relationships within the community and outside of it for his interactions-"filius" ("son") and "frater maior" ("older brother") among many others (13r). He includes words for sickness, goodness and morality, health, hunger, thirst, and famine (31r). These terms enable him and other missionaries to evaluate the physical and spiritual health of a community, incorporating phrases like "sendo eu bom" ("being good", in the first person) for confession to "matar mininos" ("kill children") in order to assess crime (29r, 32v). While he is not specific, he covers the terms that the Jesuits felt were of most concern for confessing crimes: "homê matador" ("man killer"), "homem mata mininos" ("man kills children"), "homem ladrão" ("thief"), "comedor de carne humana" ("eater of human flesh"), and "boquitorto" ("liar" or "twisted mouth") (32v). Finally, he includes relational terms for establishing a missionary presence in a village. These terms include how a missionary would identify himself as a Father ("Sum tibi in patrem", or "I am a father to you") and as a teacher, "sou mestre" ("I am a teacher") or "moromboeçáraixî" (47r). Anchieta's grammar reveals purposiveness and functionality; it confronts the crimes that he assumed Tupí society could commit, including his own expectations about cannibalism, while also giving a diverse array of verbs and nouns for day-to-day conversation. It reveals his expectations about retaining authority via "sum tibi in patrem" ("I am a father to you"), but censors or "reduces" any specific cultural flavour that could be described as Tupí (Laborie 57). While many Spanish grammars and dictionaries incorporate words for animals, drinks, and clothing that the Spaniards did not recognize or have a word for ${ }^{43}$ Anchieta's grammar avoids them, teaching the word for "food" but nothing more. Readers are left bereft of everything save being conversant, having no cultural context or knowledge.

Anchieta introduces verb conjugation early in his text in comparison to some grammarians before him (17v). In pedagogical texts like grammars, the verbs given as examples for conjugation are the ones of primary importance functionally and they typically define being and existing in the world. Many grammarians cite the tradition of Antonio de Nebrija and his Arte de la lengua castellana (1492), where he conjugates "amar" ("to love"), "leer" ("to read"), "oír" ("to listen"), "ir" ("to go"), "ser" ("to be"), and "haber" ("to exist") for readers (Book V). ${ }^{44}$ Missionaries in the New World sometimes chose to deviate, depending on what they felt was important to their own project and region, but "amar" and the sample sentence "Pedro ama a Dios" ("Peter loves God") are very common (Molina 1571; Montoya 1640; Torres Rubio 1754). Two Portugueselanguage grammars appeared before Anchieta's work: Fernando Oliveira's Grammatica da lingoagem portuguesa (1536) and João de Barros's Grammatica da lingua Portuguesa (1540). Oliveira introduces examples for "amar" ("to love"), "falar" ("to talk"), "fazer" ("to do"), "dormir" ("to sleep"), "ouvir" ("to hear"), "querer" ("to want"), and "pensar" ("to think") among a few others, though his demonstration for conjugating is not nearly as in-depth as Nebrija's ("Capitolo xlvii"). In contrast, João de Barros offers "amar" ("to love"), "leer" ("to read"), "ouvir" ("to hear"), and "ser" ("to be"), which is very close to Nebrija ("Do

\footnotetext{
${ }^{43}$ In particular, those like Alonso de Molina's Spanish-Nahuatl Vocabulario (1555) or Domingo de Santo Tomas's Spanish-Quechua Lexicón (1560).

${ }^{44}$ It is important to note that the Arte de la lengua castellana (1492) is upheld as the text par excellence for the Spanish project of creating a language of "empire"; however, Nebrija's most popular text was his Introductiones latinae (1481). The verbs used in this text are "amo" ("I love"), "doceo" ("I teach"), "lego" ("I read"), "audio" ("I listen"), and "sum" ("I am"). These verbs, of course, pull from the tradition of Donatus.
} 
Verbo").

The strongest influence in the Jesuit educational tradition, however, is Manuel Álvares's De Institutione Grammaticae (1572); many Portuguese missionaries and the entire Jesuit education system favoured this grammar. It is likely that Anchieta had at least heard of Álvares's work and that Figueira was exposed to it in his own education (Zwartjes, "The Description" 20). Álvares offers a robust series of conjugations, and begins his series with verbs of the same theme: "esse" ("to be"), "amare" ("to love"), "docere" ("to teach"), "legere" ("to read"), "audire" ("to listen"), "utor" ("to use"), and on. As always, "to love" remains an important verb. Anchieta's own conjugations mark a departure from this tradition entirely. His early verbs include: "matar" ("to kill"), "lembrar" ("to remember"), "alegrarse" ("to rejoice", loosely), "ir" ("to go"), "dizer" ("to say"), "querer" ("to want"), and "creer" ("to believe" or "to think") (17v-20r, 21r, 22v, 23r, 27r). The difference between Anchieta's verb preferences and the preferences of grammarians before him suggest that these verbs were deliberate choices, marked by the violence of the conflicts where he served as interpreter but also marked by the ecstatic joy of religion and belief.

Figueira's text neglects nouns in favour of introducing verbs right after a phonemic and allophonic assessment that spans a mere two pages (1-2). The very first verb he selects for conjugation is "matar", and he spends over twenty entire pages doing it, starting with the present tense-"eu mato" ("I kill"), "tu matas" ("you kill"), etc. (12). Following "matar", he uses an abbreviated formula of his demonstration with matar to conjugate verbs that he introduces in the first person singular: "lembro" ("I remember"), "digo" ("I say"), "venho" ("I come"), "morro" ("I die"), "entro" ("I enter"), "derrubo" ("I destroy" or "I overthrow"), and "tomo" ("I take") (36-53, 54-55, 56, 59, 60, 61). The striking emphasis on "matar" alongside "morro" and "derrubo" stands in direct contrast to Anchieta's own very functional grammar, which acknowledges "matar"-and various phrases regarding death-but does not systematically dwell on it. Figueira's text suggests that by the 1620s in northeastern Brazil, death was the greatest concern. While he shows interest in prepositions, how to convey relativity, time, and spatial markers, his language always revolves back to points of conflict. On the same page as "Coufa branca" or "Tînga" ("white thing"), the reader encounters "Hum homem morreo" ("A man died") and "matador" ("killer") (69). ${ }^{45}$

Figueira's selection of verbs to conjugate over the course of the book-related to memory ("lembrar"), contact ("dizer", "vir", and "entrar") and conquest ("derriber", "tomar", "morrer", and of course "matar")—point to the lived violence of settlers and Tupí in Maranhão, a rich source of sugar and other crops. Rather than following the trends found in Nebrija, Oliveira, Barros, and Álvares, Figueira follows Anchieta and expands on his emphasis extensively. Through the 1620 s and 1630 s, the economic scramble for slave labour and crop expansion exacerbated ongoing conflicts between the Portuguese and French and increased Portuguese violence against the Tupí. The unrestricted lives of settlers, who rebelled against both the crown and the Jesuits regarding the humanity of the Tupi and their right to freedom, embittered many in the province and forced indigenous populations to flee into the interior. In spite of Figueira wanting to "abrir as vias de comunicação entre os missionários e os índios do Maranhão", his selection of

45 Trans.: "A man died" and "killer", respectively. 
verbs suggests that contact went hand-in-hand with conquest (Magalhães 376, 377). ${ }^{46}$ For Figueira, the limits of space in a grammar and his resistance in following his predecessors and their tradition point to how deliberately these verbs were chosen in response to Anchieta and to violence in Brazil.

However, in tandem with the relationship between settler arrival and Tupí capture, "lembrar" ("to remember") is the verb that Figueira choses to conjugate immediately after "to die" (36-53). "Lembrar" stands out as the only reflexive verb to be conjugated fully and points to its utility for both individual and group memory during the interview and conversion process. An important phrase like "Eu me lembro" ("I remember") triggers memories of interactions, thoughts, and events and could also be used for ethnographic purposes. In his examples, Figueira often pairs "lembrar" with "Oxalá" ("Let's hope...") and other expressions of hope, like "Praza a Deus que me lembre", suggesting urgency but also invoking God $(36,43) .{ }^{47}$ Rather than highlighting material culture throughout his grammar, however, he focuses on actions between individuals and groups through his conjugated verbs of violence and conquest ("matar", "derriber", "tomar", "morrer") and contact ("dizer", "vir", and "entrar"). Having the extended conjugation of "matar" next to "lembrar" suggests that his experiences in Maranhão were tied to violence first and foremost, but that his experiences were also deeply influenced by the interaction with, and conversion of, speakers of Tupí.

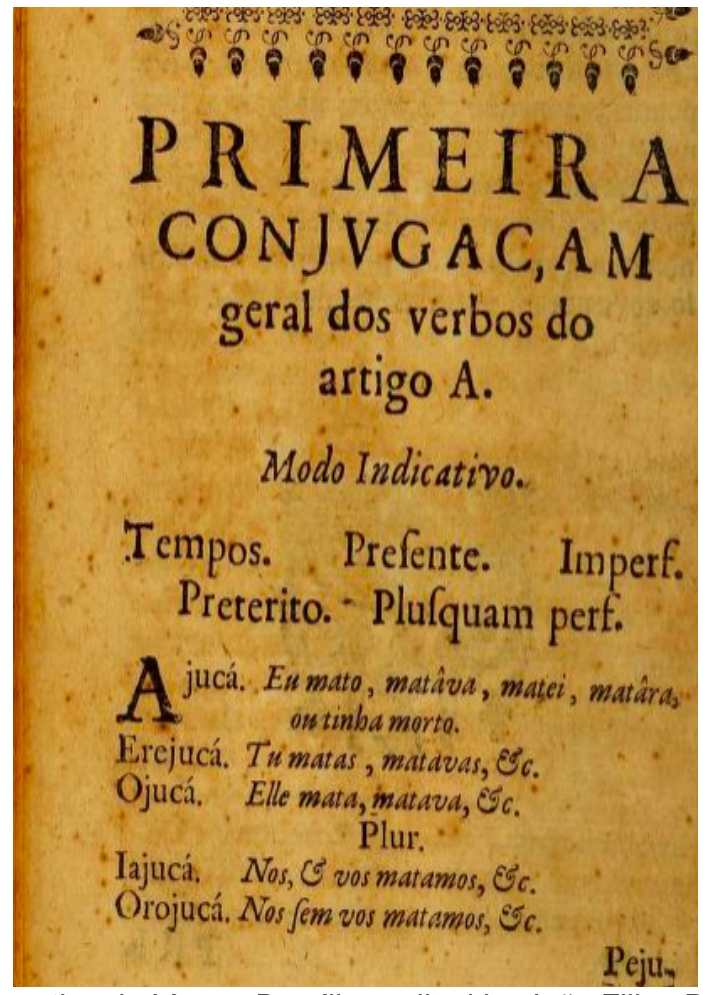

Fig. 1. Figueira, Luís. Arte de Gramatica da Língua Brasílica, edited by João Filipe Bettendorf, Na Officina de Miguel Deslandes, 1687, p.12. Courtesy of the John Carter Brown Library at Brown University in Providence, Rhode Island (open access, image provided by the author). Titled "Primeira Conjugaçam dos verbos do artigo A", this early section begins with basic tenses before moving onto more complex conjugations of the verb "matar" over the course of

${ }^{46}$ Trans.: "open the pathways of communication between the missionaries and the Indians of Maranhão."

${ }^{47}$ Trans.: "Praise be to God, may I remember." 
twenty-four pages.

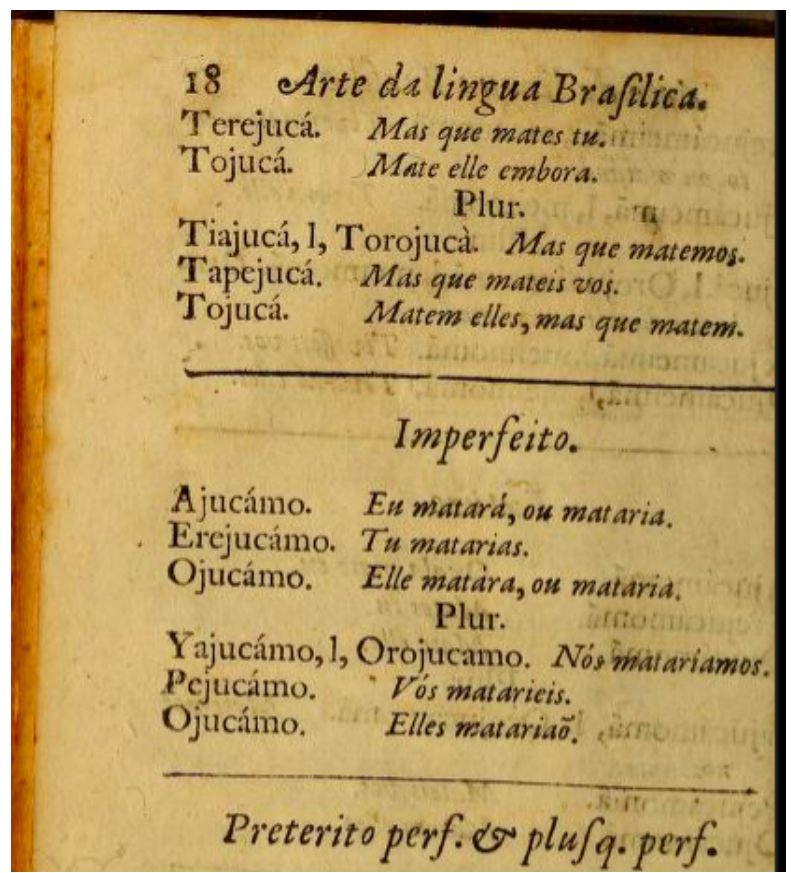

Fig. 2. Figueira, Luís. Arte de Gramatica da Língua Brasílica, edited by João Filipe Bettendorf, Na Officina de Miguel Deslandes, 1687, p. 18. Courtesy of the John Carter Brown Library at Brown University in Providence, Rhode Island (open access, image provided by the author). This image shows more complex conjugations of the verb "matar" (18).

Figueira's emphasis on relationality for family members, while socially ethnographic and similar to Anchieta's, also includes the words for "inimigo" ("enemy") and "namorado" ("lover"), implying a complex state of affairs between different tribes and individuals (73). The slippage in cultural censorship regarding social interactions, a kind of admonition, does not extend as far as cultural markers such as food, clothing, customs, or rituals, as mentioned previously in his omission of words for material objects. Like Anchieta, anything that is unnecessary or not recognizably European is left out over Figueira's greater concerns: "barbaro" ("barbarian"), "matar gente" ("kill people"), "comer gente" ("eat people"), "tenho em costume matar gente" (I have the custom of eating people"), "cosa morta" ("dead thing"), "o matador" ("the killer"), "Quero matar" ("I want to kill"), and "Deos morreo, quanto mais nos morrerémos" ("God died, how much more will we die") $(76,86,90,105,108,117,155,157,163)$. This emphasis on death reflects the region that he censors culturally, revealing the conflict, struggle, and danger that the Tupí faced.

Figueira also offers a word for God, "Tûpã", which is confirmed in his phrase "Pedro ama a Deos" ("Peter loves God") or "Pedro oçauçub Tupána" $(76,153) .{ }^{48}$ The phonetic similarity to "Tupi" suggests an attempt on the part of the Jesuits to ameliorate tensions

\footnotetext{
${ }^{48}$ Trans.: "Peter loves God." It is important to note that while this phrase is rather popular, Anchieta does

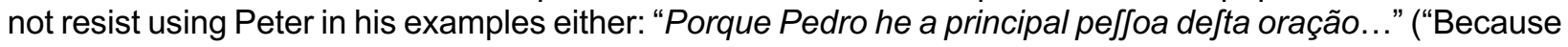
Peter is the chief part of this sentence...") (16v).
} 
between the settlers and the Tupi while simultaneously, through their own language, forcing the Christian God upon them. Using "Tûpã", a Tupí-Guaraní word, rather than a neologism or imposing a loan-word as Jakobson describes it, ${ }^{49}$ retains a careful division between Portuguese and Tupí that is not seen in Spanish and Nahuatl grammars-which use Spanish loan words extensively-or Spanish-Tagalog translations, for example (Rafael 29)..$^{50}$ This careful division on the page, represented through a strategically chosen word of familiarity that nears the universality that the word "Tupi" itself imposes on the tribes, suggests the systematic annihilation of Tupí cultural presence and its reinterpretation within Christian meaning. Figueira culls the language of the peoples he is trying to convert, erasing their culture and religion. This method reveals the insidiousness of the Portuguese translation project in the New World.

\section{Conclusions}

This study reveals how the semiotic focus in Portuguese grammars of Tupí have changed over time and have departed from European grammar-writing standards. It also shows how Early Modern culture and ideology served as a biased and manipulative filter for translation practices and goals. It demonstrates the marked and systematic silencing of Tupí oral tradition and culture at the hands of Jesuit missionaries. Using Otto Zwartjes' (and other theorists') work as a foundation, this analysis offers a brief overview of historical context, tracing the material and historical boundaries of the grammars. Polysystems theory allows for a shifting of focus onto the interplay between economy and religion surrounding the Jesuits, Portuguese settlers, and the Tupí (Even-Zohar 2004). Furthermore, the works of Bassnett and Lefevere highlight the way that translators take advantage of guiding factors in publishing and reader preference in order to make their translation more successful (Lefevere and Bassnett 11, 12; Bassnett 123). In contrast, interpreters and oral translations are limited by the power dynamics inherent to translating across oral-to-written formats and across the social dynamics of difference (Cronin 53; Tymoczko 50-54). Translations become reflections of their historical period, as well as products that patronage and religious orders can influence.

Bringing together scholarship on orality, interpretation, and the power dynamics of cultural translation (de Lima Costa 63), I have compared elements of José de Anchieta's Arte de gramática de língua mais usada na costa do brasil with Luís Figueira's Arte da Língua Brasílica. Both grammars articulate a careful censorship of Tupí life, avoiding mentions of different types of food, clothing, dance, song, and manners of living in favour of basic, functional phrases and generic terms like "food" or "drink." Instead, the grammars serve to give missionaries the basics for administering the catechisms and taking confession, in order to convert as many as possible (Hovdhaugen 14). In the case of Figueira's grammar, his text reveals a marked interest in death and all of the possible manners that one can conjugate "to kill" in Tupí. The prevalence of death reflects the

\footnotetext{
${ }^{49}$ As Jakobson wrote, the translation of an oral language from a highly subjective, social context to a written sign system can create meaning gaps and call for qualifications and "amplifications"-the expansion or transfer of meaning using more than one word-"by loan-words or loan-translations, neologisms, or semantic shifts" (115).

50 "Tu" meaning "admiration" and "pa" meaning "question", according to Renate Dürr in Translating Catechisms, Translating Cultures: The Expansion of Catholicism in the Early Modern World (2017), p. 71. It was also the word originally used to refer to the Tupi-Guarani god of thunder (75).
} 
escalation of contemporaneous conflicts, on both the cultural and physical fronts, in Brazil's northeast. However, this performance of censorship and of difference, or what Homi Bhabha calls "differential identities", reveals that the negotiation of oral and textual space is always contingent, "remaking boundaries" and "exposing the limits of any claim to a singular or autonomous sign of difference" (313). While the grammars individually reveal little about lived Tupí culture in the period, a comparative approach highlights "cultural difference" over time or the "element of resistance ... which does not lend itself to translation" (321). Despite trying their utmost to erase Tupí culture from their grammars, the systematic erasure in fact suggests the strong influence that Tupi culture and life had on them. The stark functionality of Anchieta's dictionary, useful for quotidian activity, belies the fact that he interacted with the Tupí daily, made forays into their villages, educated their children, observed their ceremonies, and spoke to their families. While Figueira's grammar fixates upon death, in all its iterations and translations, it also highlights the shift in historical climate toward hostility but also resistivity on the part of the Tupí. Through its prevalence, "matar" lends itself to translation in the grammars but simultaneously becomes a point of resistance, a word that resounds as something to be feared by colonists and missionaries alike, even as it is translated from spoken word to marks on a page.

\section{Works Cited}

de Abreu, João Capistrano. Chapters of Brazil's Colonial History, 1500-1800. Translated by Arthur Brakel, Oxford UP, 1997.

de Almeida, Cândido Mendes. "Por que razão os indígenas do nosso literoal chamavan aos franceses "Maïr" e aos protugueses "Peró?" Revista do Instituto Histórico e Geográfico Brasileiro, vol. 41, no. 2, 1878, pp. 71-141.

Alvarado, Francisco de Vocabulario en lengua misteca. Mexico City, 1593.

Álvares, Manuel. Emmanvelis Alvari è Societate lesv de institvtione grammatica libri tres. Olysippone, 1572.

de Anchieta, José de. Arte de gramática de língua mais usada na costa do brasil, Feyta pelo padre loseph de Anchieta de Cõpanhia de IESV. Coimbra, 1595.

---. "Informação do Brasil e de suas Capitanias - 1584." Cartas, Informações, Fragmentos Históricos e sermões do Padre Joseph de Anchieta, Civilização Brasileira, 1933.

Bhabha, Homi K. "How Newness Enters the World: postmodern space, postcolonial times, and the trials of cultural translation." The Location of Culture, Routledge, 1994, pp. 303-338.

Ballot, Josep Pau. Grámatica de la lengua castellana: dirigida á las escuelas. Barcelona, 
1795.

de Barros, João. Grammatica da lingua portuguesa. Olyssipone, 1540.

Bassnett, Susan. "The Translation Turn in Cultural Studies." Constructing Cultures: Essays on Literary Translation, edited by Susan Bassnett and André Lefevere, Multilingual Matters, 1998, pp. 123-140.

Bertonio, Ludovico. Arte y gramática muy copiosa de la lengua aymara. Rome, 1603.

Bethell, Leslie, editor. Colonial Brazil. Cambridge University Press, 1987.

Blancas de San Jose, Francisco. Arte y reglas de la lengua Tagala. Bataan, 1610.

Bohannan, Laura. "Shakespeare in the Bush." Natural History 75 (1966): 28-33.

Calvo Pérez, Julio. "Fonología y ortografía de las lenguas indígenas de América del Sur a la luz de los primeros misioneros gramáticos." Amsterdam Studies in the Theory and History of Linguistic Science Series 3, 109 (2005): 137-170.

Cardoso, Simão. Historiografía Gramatical (1500-1920)" Lingua Portuguesa, Autores Portugueses. Faculdade de letras do Porto, 1994.

de Caminha, Pedro Vaz. "The Discovery of Brazil." Portuguese Voyages, edited by Charles David Ley. London, J.M. Dent, 1947, pp. 41-54.

Clements, J. Clancy. The linguistic legacy of Spanish and Portuguese: Colonial expansion and language change. Cambridge University Press, 2009.

Cronin, Michael. "The Empire Talks Back." Translation and Power, edited by Maria Tymoczko and Edwin Gentzler, University of Massachusetts Press, 2002, pp. 4562.

Diffie, Bailey Wallys. A history of colonial Brazil, 1500-1792. Krieger Publishing Company, 1987.

Dürr, Renate. "Reflection on Language in Christian Mission: The Significance of Communication in the Linguistic Concepts of José de Acosta sj and Antonio Ruiz de Montoya sj." Translating Catechisms, Translating Cultures: The Expansion of Catholicism in the Early Modern World, edited by Antje Flüchter and Rouven Wirbser, Brill, 2017, pp. 50-91.

Even-Zohar, Itamar. "The position of translated literature within the literary polysystem." The Translation Studies Reader, edited by Lawrence Venuti, Routledge, 2004, pp. 192-197. 
Figueira, Luís. Arte de Gramatica da Língua Brasílica, edited by João Filipe Bettendorf. Lisboa, $\mathrm{Na}$ Officina de Miguel Deslandes, 1687. Internet Archive, archive.org/details/artedagrammatica00figu/page/n5. Accessed 4 Dec. 2008.

Gauz, Valéria. "Early printing in Brazil." Bulletin du bibliophile, no. 1, 2013, pp. 23-47.

Geertz, Clifford. The Interpretation of Cultures, Basic Books, 1973.

González Holguín, Diego. Vocabulario de la lengua general de todo el Perú llamada lengua qquichua, o del Inca. Ciudad de los Reyes, 1608.

Hanks, William F. "Word and Image in a Semiotic Perspective." Word and Image in Maya Culture, edited by William F. Hanks and Don S. Rice, University of Utah Press, 1989, pp. 8-17.

Hanks, William F. Converting words: Maya in the age of the cross. Univ of California Press, 2010.

Horace. "The Art of Poetry." Classical Literary Criticism. Translated by Penelope Murray and T.S. Dorsch. Penguin Books, 2004, pp. 98-112.

Hovdhaugen, Even, "Missionary Grammars-An Attempt at Defining a Field of Research." ... and the Word was God: Missionary Linguistics and Missionary Grammar, edited by Even Hovdhaugen, Nobus Publikationen, 1996, pp. 9-22.

Jakobson, Roman. "On Linguistic Aspects of Translation." The Translation Studies Reader, edited by Lawrence Venuti. New York, Routledge, 2004, pp. 113-118.

Kittiya Lee, Monica. Conversing in colony: the Brasilica and the Vulgar in Portuguese America, 1500-1759. 2006. Johns Hopkins University, PhD dissertation.

Laborie, Jean-Claude. "From Orality to Writing: The Reality of a Conversion through the Work of the Jesuit Father José de Anchieta (1534-1597)." Diogenes vol. 48, no. 3, 2000, pp. 56-71.

Lefevere, André. "Translation: Its Genealogy in the West." Translation, History, and Culture, edited by Susan Bassnett and André Lefevere, Pinter Publishers, 1990, pp. 46-55.

Lefevere, André and Susan Bassnett. "Introduction: Proust's Grandmother and the Thousand and One Nights: The 'Cultural Turn' in Translation Studies." Translation, History, and Culture, edited by Susan Bassnett and André Lefevere, Pinter Publishers, 1990, pp. 1-13.

Leite, Yonne de Freitas. Línguas indígenas: memórias de uma pesquisa infinda, edited by Bruna Franchetto and Thiago Coutinho-Silva, 7Letras, 2012. 
Leite, Yonne de Freitas, Marília Facó Soares, and Tania Clemente de Souza. "O papel do aluno na alfabetização de grupos indígenas: a realidade psicológica das descrições lingüísticas." Sociedades indígenas e indigenismo no Brasil, edited by João Pacheco de Oliveira Filho, Editora Marco Zero/Universidade Federal do Rio de Janeiro, 1997, pp. 241-263.

de Lima Costa, Claudia. "Feminismo e tradução cultural: sobre a colonialidade do gênero e a descolonização do saber." Portuguese Cultural Studies, vol. 4, 2012, pp. 4165.

Macdonald, N. P. The Making of Brazil: Portuguese Roots 1500-1822. The Book Guild Ltd, 1996.

Magalhães, Pablo Antonio Iglesias. "A Palavra e o império: A Arte da Língua Brasilica e a conquista do Maranhão." Revista de História, vol. 165, 2011, pp. 367-401.

de Molina, Alonso. Vocabulario en la lengua Castellana y Mexicana. Mexico City, 1555.

---. Arte de la lengua mexicana y castellana. Mexico City, 1571.

de Montoya, Antonio Ruiz. Arte, y vocabulario de la lengua guarani. Juan Sanchez, 1640.

Moss, Ann, "Copia." Encyclopaedia of Rhetoric, edited by Thomas O. Sloane, 2001, pp. 175-77.

Munday, Jeremy. Introducing Translation Studies: Theories and Applications. $3^{\text {rd }}$ ed., Routledge, 2012.

Muru, Cristina. "Early Descriptors and Descriptions of South Asian Languages from the 16th Century Onwards." Journal of Portuguese Linguistics, vol 17, no. 1, 2018, pp. 1-29.

de Nebrija, Antonio. Dictionarium latino-hispanicum. Salamanca, 1492.

---. Arte de la lengua castellana. Salamanca, 1492.

Niranjana, Tejaswini. Siting Translation: History, Poststructuralism and the Colonial Context. University of California Press, 1992.

Oliveira, Fernando. Grammatica da lingoagem portuguesa. Lisbon, 1536.

Rafael, Vicente L. Contracting Colonialism: Translation and Christian Conversion in Tagalog Society Under Early Spanish Rule. Duke University Press, 1993.

Rodrigues, Aryon Dall'Igna. "Descripción del tupinambá en el período colonial: el Arte de 
José de Anchieta." La descripción de las lenguas amerindias en la época colonial, edited by Klaus Zimmermann, Iberoamericana Vervuert, 1997, pp. 371-400.

Rodrigues, Aryon Dall'Igna, and Ana Suelly Arruda Câmara Cabral. "A contribution to the linguistic history of the língua geral amazônica." Alfa: Revista de Linguística (São José do Rio Preto), vol. 55, no. 2, 2011, pp. 613-639.

Rundle, Christopher, and Vicente Rafael. "History and translation: the event of language." Border Crossings: Translation Studies and other disciplines, edited by Yves Gambier and Luc van Doorslaer, John Benjamins, 2016, pp. 23-47.

de Santo Tomás, Domingo. Lexicón, o Vocabulario De La Lengua General Del Perú, edited by Julio Calvo Pérez and Henrique Urbano, USMP/Universidad de San Martín de Porres, Fondo Editorial, 2013.

Santiago, Silviano. "O entre-lugar do discurso latinoamericano." Uma literatura nos trópicos, edited by Silviano Santiago, Editora Perspectiva, 1978, pp. 11-28.

Tymoczko, Maria. "Translation in Oral Tradition as a Touchstone for Translation Theory and Practice." Translation, History, and Culture, edited by Susan Bassnett and André Lefevere, Pinter Publishers, 1990, pp. 46-55.

Wehling, Arno, Maria José C. De M. Wehling, and José Luiz Werneck da Silva. Formação do Brasil colonial. Nova Fronteira, 1994.

Zwartjes, Otto. Portuguese Missionary Grammars in Asia, Africa and Brazil, 1550-1800. John Benjamins Publishing Company, 2011.

---. "The Description of the Indigenous Languages of Portuguese America by the Jesuits During the Colonial Period: The Impact of the Latin Grammar of Manuel Álvares." Historiographia linguistica, vol. 29, no.1, 2002, pp. 19-70.

---. "The Missionaries' contribution to translation studies in the Spanish colonial period: The 'mise en page' of translated texts and its functions in foreign language teaching." Amsterdam Studies in the Theory and History of Linguistic Science. Series 3: Studies in the History of Linguistics, vol. 122, 2014, pp. 1-55. 